\title{
FIRST RECORD OF BERAEA DIRA MCLACHLAN 1875 (INSECTA, TRICHOPTERA, BERAEIDAE) IN CROATIA
}

\author{
Renata ĆuK ${ }^{1}$, Ivan VučKović ${ }^{2}$, Mladen Kučinić ${ }^{3}$, Damir Valić ${ }^{4}$ \\ \& JOHANN WARINGER ${ }^{5}$
}

${ }^{1}$ Hrvatske vode, Central Water Management Laboratory, Ulica grada Vukovara 220, 10000 Zagreb, Croatia (renata.cuk@voda.hr)

2Elektroprojekt d.d., Civil and Architectural Engineering Department, Alexandera von Humboldta 4, 10000 Zagreb, Croatia

${ }^{3}$ Department of Biology (Laboratory for Entomology), Faculty of Science, University of Zagreb, Rooseveltov trg 5, 10000 Zagreb, Croatia

${ }^{4}$ Institute Ruđer Bošković, Laboratory for Aquaculture and Pathology of Aquatic Organisms, Bijenička cesta 54, 10000 Zagreb, Croatia

${ }^{5}$ University of Vienna, Department of Limnology and Oceanography, Vienna, Austria

Ćuk, R., Vučković, I., Kučinić, M., Valić, D. \& Waringer, J.: First record of Beraea dira McLachlan 1875 (Insecta, Trichoptera, Beraeidae) in Croatia. Nat. Croat., Vol. 24, No. 2, 311-316, 2015, Zagreb.

The caddisfly species Beraea dira McLachlan 1875 was recorded for the first time in Croatia in the upper course of the Bistrac River in October 2014.

Key words: caddisfly, new record for Croatia, Bistrac River

Ćuk, R., Vučković, I., Kučinić, M., Valić, D. \& Waringer, J.: Prvi nalaz vrste Beraea dira McLachlan 1875 (Insecta, Trichoptera, Beraeidae) u Hrvatskoj. Nat. Croat., Vol. 24, No. 2, 311-316, 2015, Zagreb.

Tular Beraea dira McLachlan 1875 je po prvi put utvrđen na području Hrvatske u gornjem toku rijeke Bistrac u listopadu 2014. godine.

Ključne riječi: tulari, nova vrsta za Hrvatsku, rijeka Bistrac

\section{INTRODUCTION}

The order Trichoptera, or caddisflies, includes 14,548 extant species (Morse, 2015), more than 1,400 of which occur in Europe (MaLicky, 2004). Trichoptera have evolved into a highly diverse fauna that exploits nearly all aquatic habitats (GrAF et al., 2008a).

In the last two decades systematic research of caddisflies has been conducted in Croatia, resulting in a relatively good knowledge of the caddisfly fauna of certain areas (e.g. Plitvice Lakes National Park, the Cetina River, the Dobra River, the Krka River). In this period several new species and subspecies have been discovered (Previšić et al., 2014; Kučinić et al., 2013; OláH, 2010, 2011; Malicky et al., 2007; Kučinić \& Malicky, 2002). Caddisfly females (Kučınić et al., 2014; VučKović et al., 2011) and larvae (Previšıć et al., 2014; WARINGer et al., 2009; GrAf et al., 2008b; KučInić et al., 2008) have been described from specimens collected in Croatia. Furthermore, due to all thie research as well as national monitoring of surface water quality a high number of species has been recorded for the first time (e.g. ĆUK \& VučKović, 2014; Previšić et al., 2012; KučInić et al., 2011). 
However, some parts of Croatia are still poorly investigated and more detailed research should be conducted.

Considering the available literature data, previous research and individual records, the number of documented caddisfly species in Croatia is around 200 and it is estimated that in total 220-240 species might occur in Croatia.

This paper presents the first record of Beraea dira McLachlan 1875 in Croatia.

\section{RESEARCH AREA}

The Bistrac (Bistrica) River is situated in the Dinaric ecoregion (ER5) (ILLIEs, 1978) and belongs to the catchment area of the Dobra River (Fig. 1a). It is a small continental river with a length of $4.5 \mathrm{~km}$ (OpAla \& OžAnić, 2010). According to national typology the Bistrac River is classified as ,"a small montane and upland rives“ (NARODNE NOvine, 73/13). The study site at the Bistrac River is located approximately $20 \mathrm{~km}$ from the city of Ogulin, near the settlement of Trošmarija (Fig. 1b). The dominant substrates were lithal (macro-, meso- and microlithal) and phytal (HRN EN 16150) (Fig. 2).

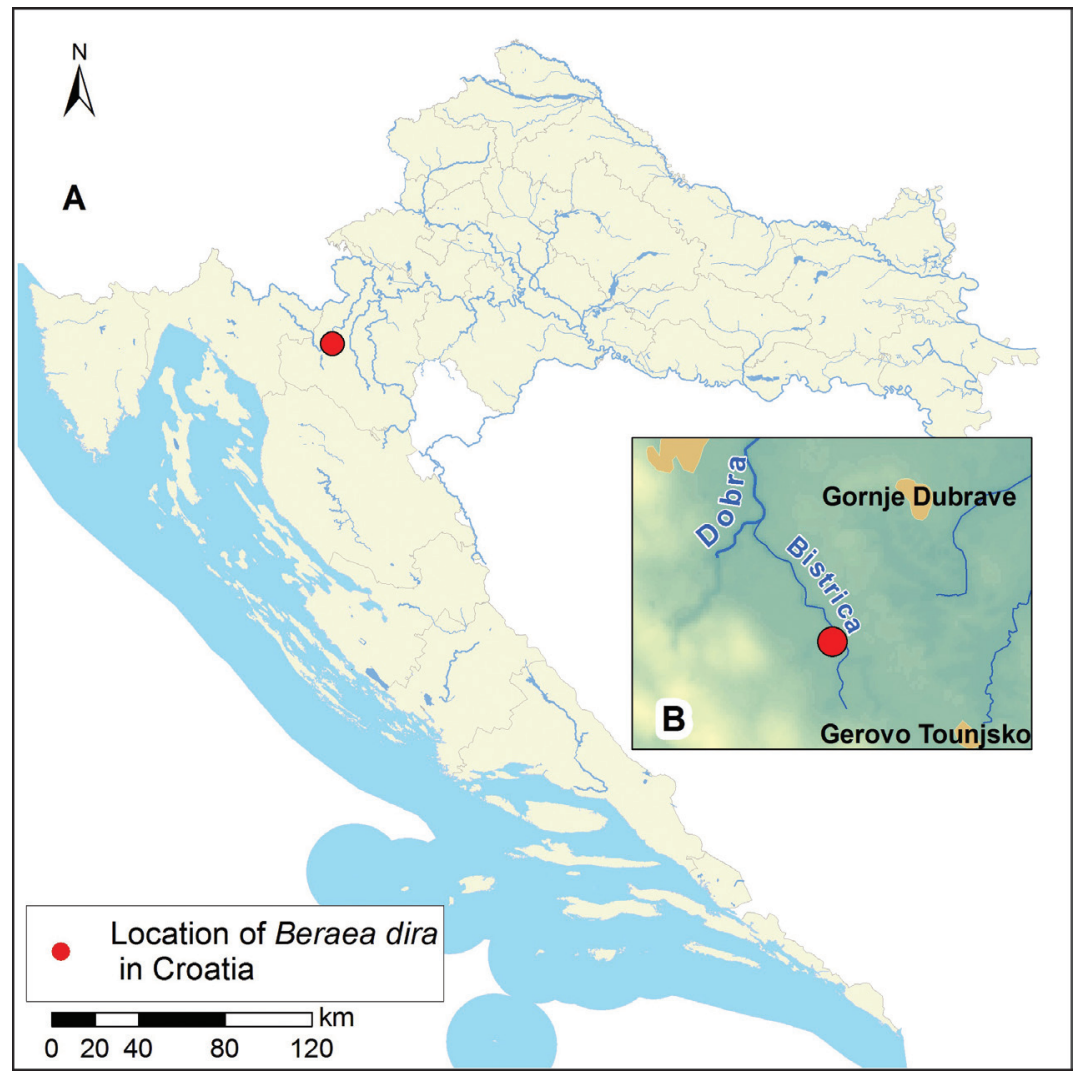

Fig. 1a. A map of Croatia with a record of $B$. dira (red spot); b) detail of the study area 


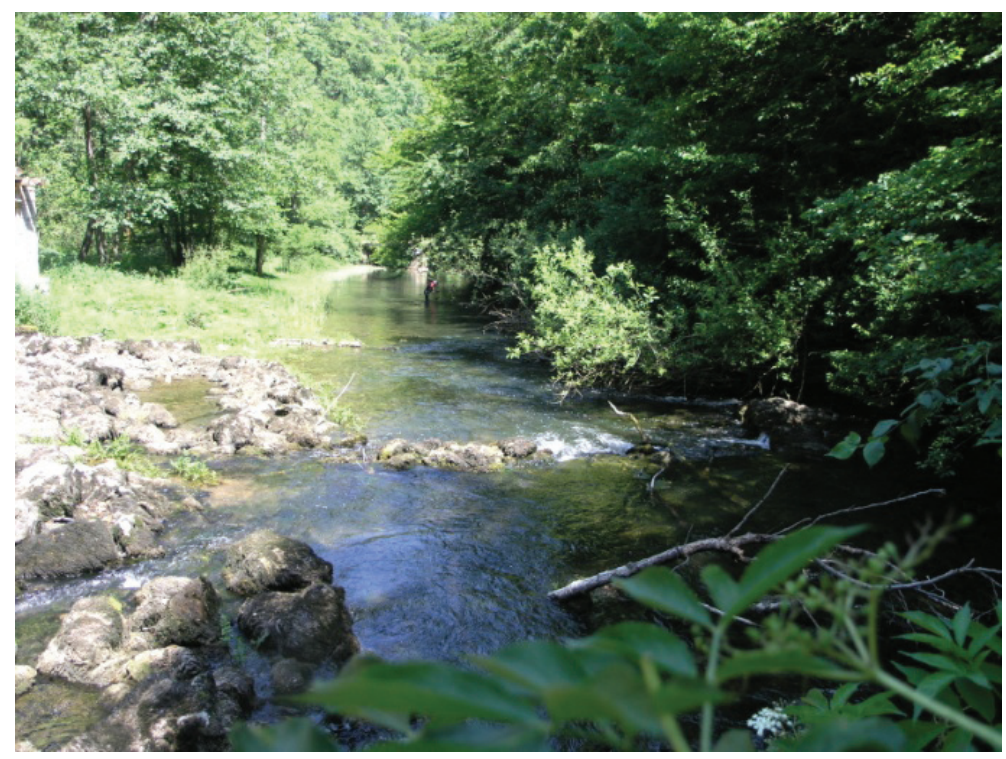

Fig. 2. The study site at the Bistrac River (photo: D. Valić)

\section{MATERIAL AND METHODS}

Samples of macrozoobenthos were collected with the use of a hand net with a mesh size of $500 \mu \mathrm{m}$ according to the AQEM sampling method (Hering et al., 2004). All microhabitats represented with a more than $5 \%$ coverage were sampled. The collected material was preserved with ethanol in the field so the final concentration was cca $70 \%$. Determination of benthic macroinvertebrates was done in the laboratory with the use of a binocular stereomicroscope (Olympus SZX10). For determination, the keys of WARINGER \& GRAF (2011) and LechthALER \& STOCKINGER (2007) were used.

All specimens have been deposited in the collection of caddisflies in the Central Water Management Laboratory of Hrvatske vode.

\section{RESULTS AND DISCUSSION}

In October 2014 four larval specimens of $B$. dira were recorded in the upper course of the Bistrac River. According to Fauna Europaea (Malicky, 2013), the species does occur in Croatia. However, due to the lack of data on locality of records in this database, as well as the absence of the species from any other available literature data and previous research, we consider this finding to be the first reliable record.

The characteristics of the larva are the following: posterior case opening is without a semicircular, lip-like prominence (Fig. 3a), posterior third of frontoclypeus broadly triangular (Fig. 3b), pronotum contains a broadly rounded lateral fold (Fig. 3c), only one carina is present at each side of the head capsule (Fig. 3c), thick terminal setae on basal sections of anal prolegs originates from yellowish-brown plates sclerotized only on ventral half of the base of seta and anterolateral setal group consists of 12 or more long setae (Fig. 3d). 


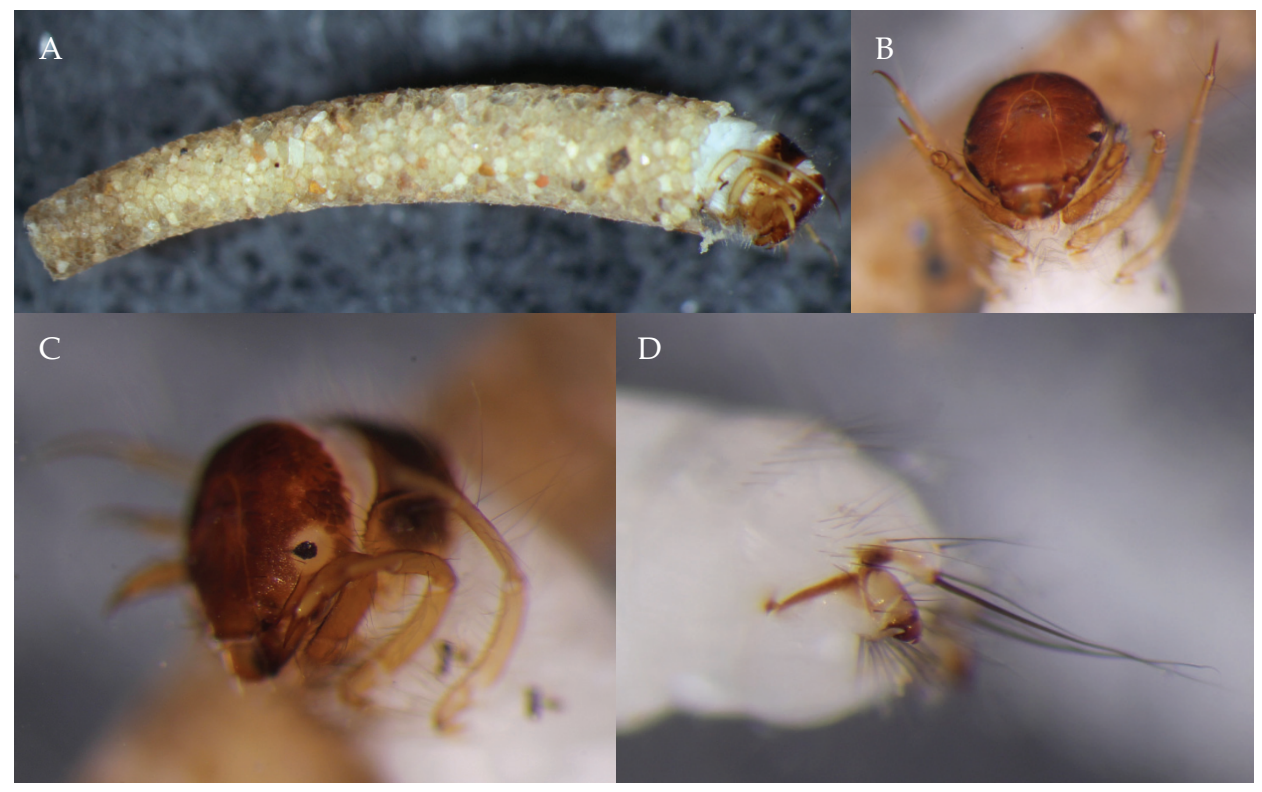

Fig. 3. Beraea dira, a) larva in its case; b) head, frontal view; c) head and prothorax, lateral view; d) anal proleg (photos: R. Ćuk)

According to Graf et al. (2008a) 18 species of the genus Beraea are present in Europe, 2 of which are widely distributed: B. maurus (Curtis, 1834) and B. pullata (Curtis, 1834), including Croatia (Kučinić et al., unpublished data), while the others are restricted to smaller regions. B. dira is recorded only in Ecoregions 4, 5 and 13 (GrAf et al., 2008a). The species is cold stenotherm, preferring temperatures below $10^{\circ} \mathrm{C}$ (GRAF et al., 2008a). It mostly occurs in the eucrenal and hypocrenal zones, less in the epirhithral zone. It prefers madicol habitats (edge of water bodies, moist substrates) avoiding current so it usually inhabits slowly flowing streams and standing waters (GrAf et al., 2008a).

The caddisfly fauna was explored in the catchment area of the Dobra River in the period 2009-2010 with around 80 species recorded (CERJANEC, 2012), which represents the largest number of caddisfly species recorded in one systematic study in Croatia (e.g. KučInIĆ, 2002; KučınIć et al., 2011; VučKović, 2011). This indicates the high faunistic diversity of the catchment area of the Dobra River due to habitat diversity and high water quality (CERJANEC, 2012). Therefore, protection and prevention of further degradation of this area should be considered s priority.

At the study site at the Bistrac River 44 benthic macroinvertebrate taxa were recorded, of which the most abundant were: Sadleriana sp., Gammarus fossarum Koch, in Panzer 1835, Echinogammarus sp., Elmis sp. and Ancylus fluviatilis O.F. Muller 1774. Besides B. dira, six caddisfly taxa were recorded: Odontocerum albicorne (Scopoli 1763), Sericostoma sp., Rhyacophila sp., Hydropsyche dinarica Marinkovic-Gospodnetic 1979, Lype reducta (Hagen 1868) and Plectrocnemia conspersa (Curtis 1834). 


\section{REFERENCES:}

Cerjanec, D., 2012: Ecological and biogeographical features of caddisflies (Insecta: Trichoptera) in different types of habitats in drainage of the Dobra River. PhD Thesis (in Croatian). University of Zagreb, pp 226, Zagreb.

Ćuk, R. \& VučKović, I., 2014: The first record of caddisfly Setodes viridis (Fourcroy, 1875) (Insecta: Trichoptera) in Croatia. Natura Croatica 23(2), 407-413.

Graf, W., Murphy, J., Dahl, J., Zamora-Muñoz, C. \& López-Rodríguez, M. J., 2008a: Distribution and ecological preferences of European freshwater organisms. Volume 1. Trichoptera. Pensoft, SofiaMoscow, 388 pp.

Graf, W., Kučinić, M., Previšić, A., VučKović, I. \& Waringer, J., 2008b: The Larva, ecology and distribution of Tinodes braueri McLachlan, 1878 (Trichoptera: Psychomyiidae). Aquatic insects 30(4), $295-299$.

Hering, D., Moog, O., SAndin, L. \& Verdonschot, P. F. M., 2004: Overview and application of the AQEM assessment system. Hydrobiologia (The Hague) 516, 1-20.

HRN EN 16150, 2012: Water quality - Guidance on pro-rata Multi-Habitat sampling of benthic macroinvertebrates from wadeable rivers, pp. 12.

ILliES, J., 1978: Limnofauna Europaea. Gustav Fischer Verlag, Stuttgart, pp. 532.

Kučınıć, M., 2002: Diversity and distribution of caddisflies (Insecta, Trichoptera). PhD Thesis (in Croatian). University of Zagreb, 138 pp. Zagreb.

Kučinić, M. \& MALICKY, H., 2002: Rhyacophila dorsalis plitvicensis new subspecies from Croatia. Proceedings of the 10th International Symposium on Trichoptera (Ed. W. MEY). Nova Supplementa Entomologica 15, 145-147.

Kučinić, M., Previšić, A., Gottstein, A., Hrašovec, B., Stanić-Koštroman, S., Pernek, M. \& Delić, A., 2008: Description of the larvae of Drusus radovanovici septentrionis Marinković-Gospodnetić, 1976 and Drusus croaticus Marinković-Gospodnetić, 1971 (Trichoptera: Limnephilidae) from Bosnia and Herzegovina and Croatia. Zootaxa 1783, 1-17.

Kučinić, M., VučKović, I., KutnjaK, H., ŠErić Jelaska, L. \& Marguš, D., 2011: Diversity, distribution, ecology and biogeography of caddisflies (Insecta: Trichoptera) in the Krka River (National Park „Krka”, Croatia). Zoosymposia 5, 255-268.

Kučinić, M., Szivák, I., Pauls, S.U., BÁlint, M., Delić, A. \& VučKović, I., 2013: Chaetopteryx bucari sp. n. a new species from the Chaetopteryx rugulosa group from Croatia (Insecta, Trichoptera) with some molecular, taxonomical and ecological notes on the group. Zookeys 320, 1-28.

Kučinić, M., Delić, A., Ćuk, R., Previšić, A., Mihoci, I., Žganec, K., Cerjanec, D. \& Vučković, I., 2014 : The first finding of Drusus bosnicus Group (Insecta, Trichoptera, Limnephilidae) in Croatia with some notes on diversity, distribution and ecology of genus Drusus in Croatia and in Dinaric karst of the Balkan Peninsula. Natura Croatica, 23(2), 265-377.

Lechthaler, W. \& Stockinger, W., 2007: Trichoptera-Key to Larvae from Central Europe. Gustav Stresemann Institut e.V. Deutsche Gesellschaff für Limnologie.

Malicky, H., 2004: Atlas of European Trichoptera, Second Edition, Springer, 359 pp.

Malicky, H., Previšić, A. \& Kučınıć, M., 2007: Rhyacophila cabrankensis nov. spec. from Croatia. Braueria 34, 14.

Malicky, H., 2013: Fauna Europaea: Trichoptera. Fauna Europaea version 2.6.2, http://www.faunaeur. org (accessed on $27^{\text {th }}$ November 2015)

Morse, J. C. (ed.), 2015: Trichoptera World Checklist. http://entweb.clemson.edu/database/trichopt/index. htm (accessed on $23^{\text {th }}$ July 2015).

NARODNE NOvine, 2013: Uredba o standardu kakvoće voda (Regulation on water quality standard). No. $73 / 13$.

OLÁH, J., 2010: New species and new records of Palearctic Trichoptera in the material of the Hungarian Natural History Museum. Annales Historico-Naturales Musei Nationalis Hungarici 102, 65-117.

OlÁH, J., 2011: New species and records of Balkan Trichoptera. Folia Historico Naturalia Musei Matraensis 35, 111-121.

Opala, I. \& OžAnıć, N., 2010: Hidrološka analiza sliva rijeke Dobre. Građevinski fakultet Sveučilišta u Rijeci, Zbornik radova (XIII) 11-33, Rijeka.

Previšić, A., Cerjanec, D., Graf, W. \& Kučinić, M., 2012: Drusus chrysotus (Rambur, 1842) (Trichoptera: Limnephilidae: Drusinae): A new caddisfly species in the Croatian fauna. Natura Croatica 21(2), 419425. 
Previšić, A., Graf, W., Vitecek, S., Kučinić, M., Bálint, M., Keresztes, L., Pauls, S.U. \& Waringer, J., 2014: Cryptic diversity of caddisflies in the Balkans: the curious case of Ecclisopteryx species (Trichoptera: Limnephilidae). Arthropod Systematics \& Phylogeny 72(3), 309-329.

VučKović, I., 2011: Faunistic, taxonomic and ecological characteristics of caddisflies (Insecta: Trichoptera) on the catchment area of the river Cetina. PhD Thesis, (in Croatian). University of Zagreb, 172 pp. Zagreb.

Vučković, I., Previšić, A., Graf, W. \& Kučinić, M., 2011: Description of the female and distribution of Annitella apfelbecki Klapálek, 1899 (Insecta: Trichoptera). Aquatic Insects 33(4), 381-389.

Waringer, J., Graf, W., Kučinić, M., Previšić, A. \& VučKović, I., 2009: The Larva and life cycle of $A n$ nitella apfelbecki Klapalek, 1899, including a re-description of Melampophylax nepos McLachlan, 1880 (Trichoptera: Limnephilidae). Aquatic insects 31(1), 71-80.

WARINGER, J. \& GRAF, W., 2011: Atlas der mitteleuropäischen Köcherfliegenlarven/Atlas of Central European Trichoptera Larvae. 468 pp., (Erik Mauch Verlag) Dinkelscherben.

\title{
SAŽETAK
}

\section{Prvi nalaz vrste Beraea dira McLachlan 1875 (Insecta, Trichoptera, Beraeidae) u Hrvatskoj}

\author{
R. Ćuk, I. Vučković, M. Kučinić, D. Valić \& J. Waringer
}

U posljednja dva desetljeća provode se detaljnija istraživanja faune tulara u Hrvatskoj (Cetina, Drava, Dobra, Krka, Kupa, Kupica i druge rijeke) prema kojima je, uz postojeće literaturne podatke i pojedinačne nalaze, do sada zabilježeno oko 200 vrsta tulara. S obzirom na nedovoljnu istraženost tulara u Hrvatskoj, procjenjuje se da bi ukupan broj vrsta mogao biti oko 220-240. Ovaj rad daje prikaz nove vrste tulara u fauni Hrvatske koja je utvrđena na temelju prikupljenih ličinki: Beraea dira McLachlan 1875 iz porodice Beraeidae. Vrsta je zabilježena u listopadu 2014. godine u rijeci Bistrac koja pripada slivu rijeke Dobre, a cijelo se područje sliva odlikuje velikom raznolikošću tulara s obzirom na brojnost različitih staništa i dobru kakvoću vode. Navedeni nalaz važan je doprinos za faunu tulara Hrvatske. 